\title{
Improvement of the production system
}

\author{
Luboslav Dulina $^{1}$, Miroslav Rakyta ${ }^{1}$, Ivana Sulirova ${ }^{1}$ and Michala Seligova ${ }^{1}$ \\ ${ }^{1}$ University of Zilina, Faculty of Mechanical Engineering, \\ Univerzitna 1, 01026 Zilina, Slovakia \\ \{luboslav.dulina, miroslav.rakyta, ivana.sulirova, \\ michala.seligova\}@fstroj.uniza.sk
}

\begin{abstract}
The article deals with improvement of the production system based on the cooperation of enterprise and university. The improvement of production system in the selected enterprise included relocation of the pre-assembly workstation to the newly created supermarket - storehouse with narrow aisles, and implementation of new supplying system based on the principle of the Kanban method. The project has brought advantages to the enterprises described in conclusion of the article, where its benefits and return on investment are calculated as well.
\end{abstract}

Keywords: improvement, cooperation, supermarket, Kanban, material flows

\section{Introduction}

The present day is characterised by high degree of informatization of society, new trends in the field of business management, and in the field of training of young people for the Factories of the Future (FoF). The key of success for industrial enterprises lies in cooperation with universities and R\&D (research and development) centres. R\&D does not relate only to universities but also companies which want to be innovative. [1] In present, cooperation as such represents for a company an important tool for increasing its competitiveness. [2] The result of such cooperation is a benefit for both sides. The enterprises will have new trends implemented, their processes will be managed more efficiently, which will bring them higher profit and they will eliminate wastes. On the other hand, universities and development centres will acquire practical knowledge and a possibility to implement their development solutions into practice.

There are new tendencies in management of production processes showing in manufacturing enterprises. As purchasing market is pushing itself through and requirements of customers are rising, together with the effort to shorten delivery periods and with plenty of variants of products' adjustments, it all causes the increase of the risk of keeping stock. New strategic concepts must fulfil the requirement of high reliability of supply, flexible production and the ability to adapt to new situations.

All enterprises create their own procedures of success, use similar methods, tools and techniques. The problem is the shortage of supplying systems supporting 
continuous flow, production in small batches and assembly workstations. To link continuous flow and zones of supplies, they lack pull signals. The result is insufficient supplying of processes with material, decrease of flow and high level of stock, which causes waste of effort and money. [3]

\section{Objective and metodology}

The result of cooperation of the enterprise and university was a complex project of implementation of several segments' production improvement. The highest savings were identified by translocation of pre-assembly workstation into another hall, and by the transformation into the pull principle. The analysis of the current state of material flows in the enterprise was processed in the AutoCAD software using FactoryCAD and FactoryFLOW tools. In these modules of the Tecnomatix software, 2D models of production system were being created, and also the optimization of the plant's layout was performed based on analyses of material flows. Based on analyses, also the ways of implementation of purchased parts' supermarket and of Kanban system were designed. The objective was to evaluate individual designs, benefits of implementation of supermarket concept, and to apply the best variant.

In enterprises, the most frequent tasks for improvement in production are: [4]

- improvement of production processes,

- improvement of production batches,

- improvement of material composition,

- improvement of production procedures,

- improvement of production planning,

- improvement of supporting processes.

The implemented project was focused on improvement of internal logistics, implementation of Kanban system, creation of supermarket and improvement of material flows.

\section{The analysis of the current state of selected enterprise}

The enterprise, where the project was implemented, produces components for automotive industry with historical experience and modern technologies. It produces wide range of products. For its spreading market operations, it needed to adapt its production system to rising amount of production. Within the project, improvement of four types of components was implemented. Each type of component is being produced in another hall. They have mutual input and output storehouse. These components were considered to be product representatives.

Based on the analyses, it was found out that technological procedures of production of representative components are composed of eighteen technological operations on average, and the production process lasts 502.5 minutes on average. The production of the smallest representative lasts 4.5 hours, and production of the biggest one lasts 18 hours. There are 6,169 pieces of these representatives produced 
per year. In Table 1, technological procedure of one type of representative is described.

Table 1. Technological procedure.

\begin{tabular}{lll}
\hline No. of operation & Name of operation & Duration of operation \\
\hline 10 & Soldering 1 & $22.14 \mathrm{~min}$ \\
20 & Soldering 2 & $22.15 \mathrm{~min}$ \\
30 & Soldering 3 & $49.98 \mathrm{~min}$ \\
35 & Pre-assembly & $4.74 \mathrm{~min}$ \\
40 & Soldering 4 & $49.98 \mathrm{~min}$ \\
50 & Pressure testing & $4.02 \mathrm{~min}$ \\
60 & Preparation of helium leak testing & $4.96 \mathrm{~min}$ \\
70 & Helium leak testing & $12.00 \mathrm{~min}$ \\
80 & Filling and vacuum forming & $9.00 \mathrm{~min}$ \\
90 & Isolating & $28.02 \mathrm{~min}$ \\
100 & Isolating of sides & $13.98 \mathrm{~min}$ \\
105 & Installation of electrical circuitry & $25.02 \mathrm{~min}$ \\
120 & Plugging in before testing & $7.98 \mathrm{~min}$ \\
130 & Complete testing & $27.00 \mathrm{~min}$ \\
140 & Plugging out after testing & $10.02 \mathrm{~min}$ \\
150 & Completion & $19.98 \mathrm{~min}$ \\
160 & Packing and dispatch & $10.02 \mathrm{~min}$ \\
\hline
\end{tabular}

Figure 1 depicts the output of analysis of the current state of material flows in form of Sankey diagram.

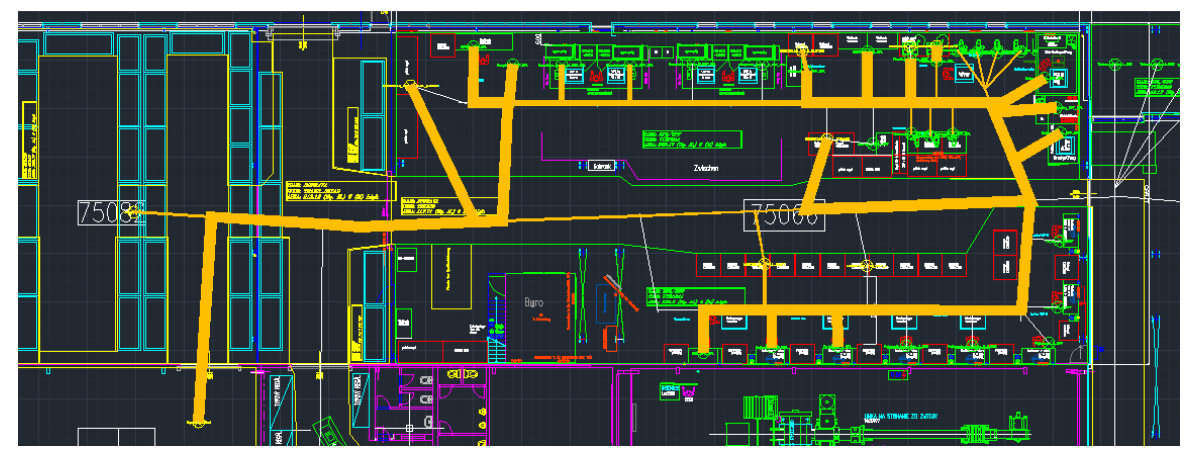

Fig. 1. Sankey diagram.

Process diagram in the Figure 2 shows production workstations and amounts of parts and unfinished products being transported among workstations, in that one type of components is being produced. Material flow starts in the input storehouse and ends in the output storehouse. 


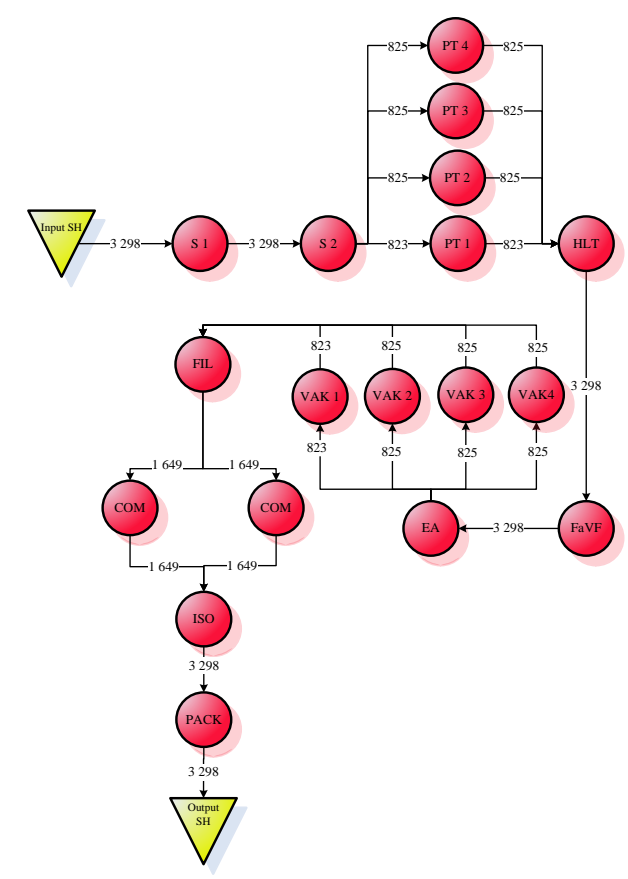

Fig. 2. Process diagram.

The input storehouse is located near production halls, and the material is being transported by fork-lift truck. The material is stored in metal gitterboxes, cardboard boxes with various sizes, rack boxes, on euro-pallets, in plastic packages or loosely. The inter-storage contains stock for workstations for one week. (Fig 3 shows an example)

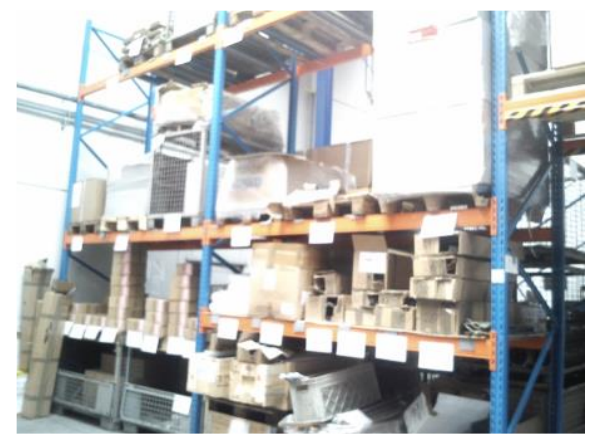

Fig. 3. Rack storehouse.

In the place of original storehouse (Fig. 4 shows an example) with the total area of $391.0 \mathrm{~m}^{2}$, there were these areas: 
- $\quad$ area of racks $145.1 \mathrm{~m}^{2}$,

- $\quad$ area for transport $145.1 \mathrm{~m}^{2}$,

- other areas $145.1 \mathrm{~m}^{2}$.

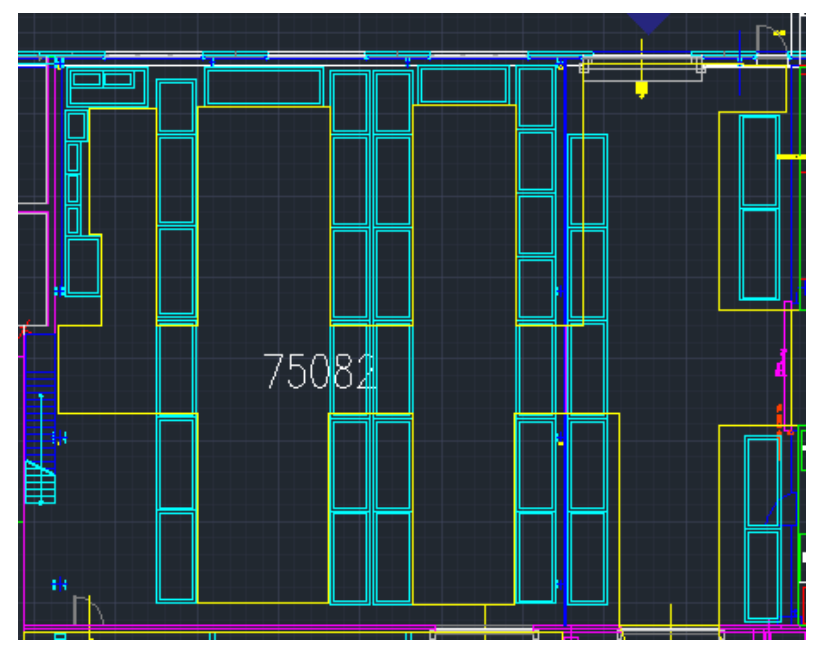

Fig. 4. Layout of input storehouse.

\subsection{Analysis of layout design and requirements of the enterprise}

Within the solution, the calculation of material flows was performed together with analysis of objects' layout, calculation of distances, costs of transport, intensity of routes' utilization, utilization of means of transport and of workstations, and Sankey diagrams. The analysis showed following results:

- the length of material flows was $293,924.41 \mathrm{~m} /$ year,

- total annual transport costs were reaching $38,173.73 € /$ year,

- the number of movements of transport devices was 112,304.12 movement / year,

- total time of manipulation and transport was 349,221.89 min / year

The outcome of utilization of transport devices' analysis is shown in Table 2.

Table 2. Utilization of transport devices.

\begin{tabular}{lllll}
\hline Device & Quantity & Busy (min) & Avail. (min) & Utilization \\
\hline Pallet truck & 4 & $306,080.52$ & $864,000.00$ & 35.43 \\
Fork-lift truck & 2 & $43,141.37$ & $432,000.00$ & 9.99 \\
\hline
\end{tabular}


The enterprise's requirement was to implement supermarket of purchased parts in the current place of maintenance. The new storehouse would have the area of $393.0 \mathrm{~m}^{2}$ at its disposal.

Criteria for improvement were set as follows:

- reduce costs of manipulation with the material,

- increase the number of pallet places in the storehouse.

\section{Identification of main aspects of implementation}

To make the new system work properly, it has to fulfil initial requirements. The Plan for Every Part will provide input information needed for designing, the supermarket will provide input material, and the new supplying system must provide communication and flows between production and storehouse. [5]

\subsection{Plan of implementation of new supplying system}

Based on experience and recommendations, sequence of steps of the new supplying system's implementation was designed for the enterprise. The new plan included following steps: [6]

STEP 1: Creation of the Plan for Every Part - PFEP, of the database containing material with numeric designation, specification of the material, supplier, supplier's location, with the place of storage and consumption, and other important information. STEP 2: Creation of one storehouse for all parts entering the enterprise.

STEP 3: Creation of supply circuits.

STEP 4: Integration of the new supplying system's management with the management information system while using pull signals.

The Plan for Every Part is a table with ordered data on materials, accessible in electronic form to every user. Its use has two main advantages:

- it enables to sort data based on categories (intensity of ordering, dimensions of transport units, hourly consumption),

- $\quad$ it enables to change and add categories with minimal effort.

For the creation of supermarket, it was needed to set maximal amount of each component, which will be needed to provide normal operation of production system. The average daily consumption of parts was determined, together with transport batch and containers needed. By the calculation of transport units needed to store the material and then multiplying them by their physical sizes, the space needed for their storage was determined.

While preparing the supermarket, it was necessary to determine: [6]

- storage system,

- positions labelling system,

- implementation of the process of storing and dispatching of parts,

- implementation of the process of reaction to excessive stock,

- minimal level of stock. 
The layout of new supermarket is shown in Figure 5. Transport area has $217.42 \mathrm{~m}^{2}$ and the area of racks has $115.5 \mathrm{~m}^{2}$.

The objective of improvement of warehousing is to increase the number of pallet places. More efficient storing with maximal utilization of space, with efficient, fast and clear material flow will be provided by storehouse with narrow aisles. Carts for narrow aisles enable maximal utilization of storehouse's space. Because of their construction, they need an aisle wide only $1.52 \mathrm{~m}$ as their forks enable three-sided inserting. [10]
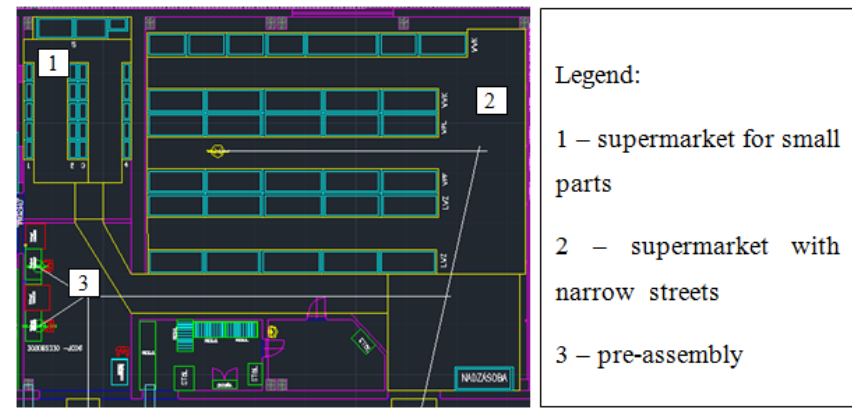

Fig. 5. Supermarket design.

Inductive guidance of the new system cart for narrow aisles is installed into the floor and it consists of one closed loop powered by frequency generator. Its scheme is depicted in Figure 6.

Designed performing of material's transport is provided by supply circuit with two-way aisles for supplying. In the design, existing aisles are being followed. Tugger with attachment is used.

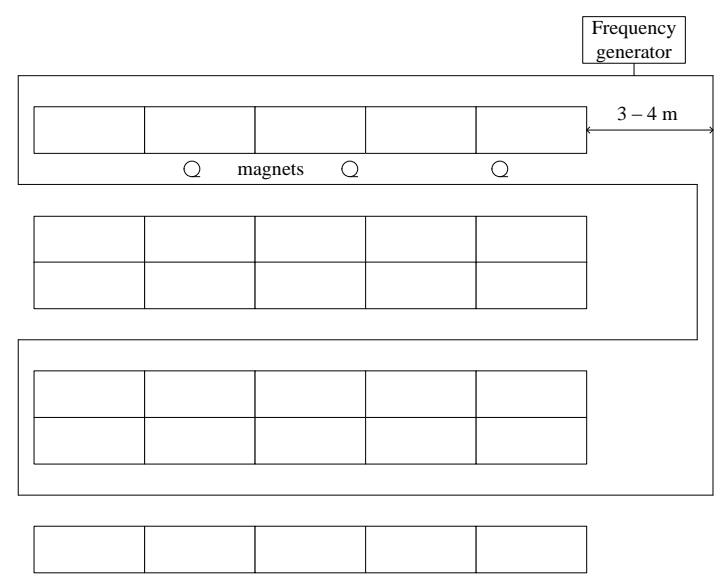

Fig. 6. Scheme of inductive line. 
To save the time of supplying person and to serve more workstations, preliminary circuit was set, amounts of transported material were calculated, and the circuit was tested. Necessary changes of truck's stops or places of supplies were made. The preliminary schematic circuit is depicted in Figure 7.

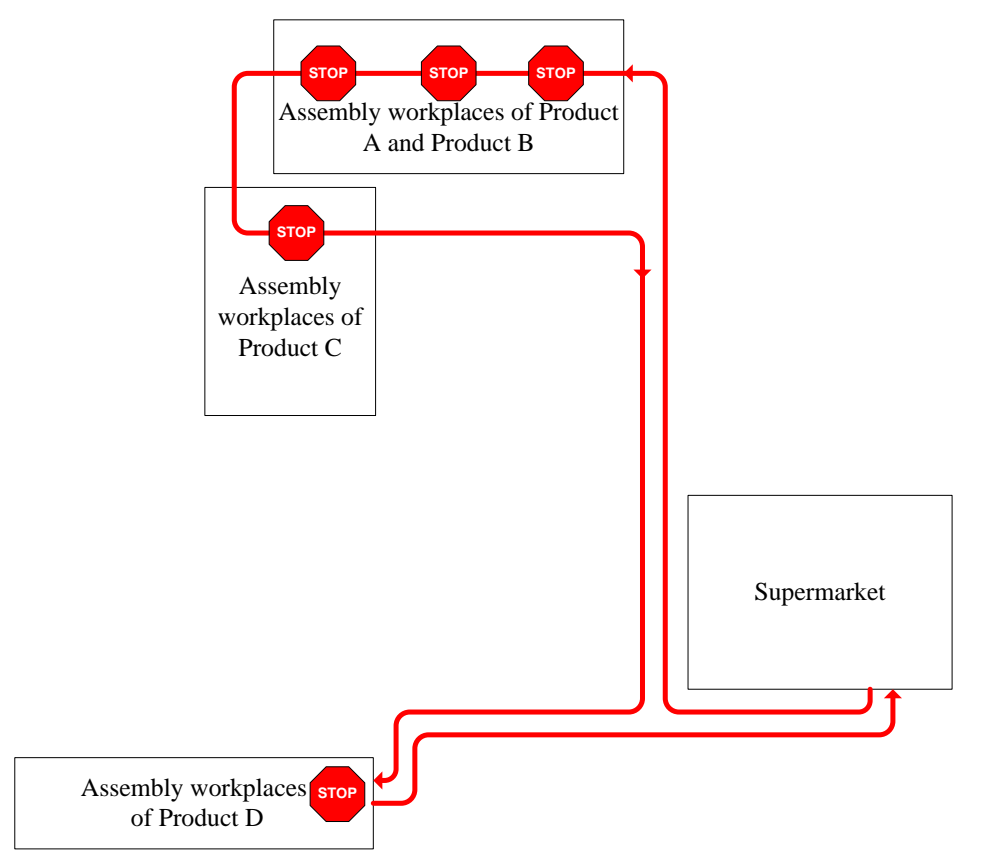

Fig. 7. Supplying circuit.

In the enterprise, the pull system was implemented with the objective to create system that is able to flexibly react to changes in demand. The aim was to reduce costs related to consumption of goods and to material flow. The implemented Kanban system in the enterprise shall aim for fulfilment of: [7]

- limited stock of material and components,

- delivering of $100 \%$ quality from supplier,

- small and proper buffer stock between workstations,

- zero defects,

- delivery of final products into storehouse according to the need,

- small (in ideal case none) stock of finished components.

To signalize the consumption of material and to move material from the supermarket, there are Kanban cards used containing information about: [8]

- material's number,

- its position in the supermarket,

- place of its delivery,

- number of cards in the place of use. 
The implemented system with higher frequency of supplying of the circuit contains less stock, and it is more sensitive to changes. The work in supermarket is eliminated by smaller transport units. With lower frequency of supplying, resources are being used more efficiently, and costs of stock are being minimized. [9]

In the designed disconnected circuit, there are dispatching person and supplying person needed. The supplying person, while supplying the circuit, collects Kanban cards, loads empty crates and pallets, passes collected cards in storehouse to the dispatching person, loads material according to previously collected cards, and repeatedly supplies the circuit. The dispatching person in the supermarket dispatches (prepares) material according to the cards brought by supplying person.

\section{Relocation of the pre-assembly to the supermarket}

By the relocation of the detached workstation of pre-assembly of a component to the supermarket, one worker as a labour resource was saved because of the merger of two workstations. Original location of the pre-assembly workstation is shown in Figure 8.

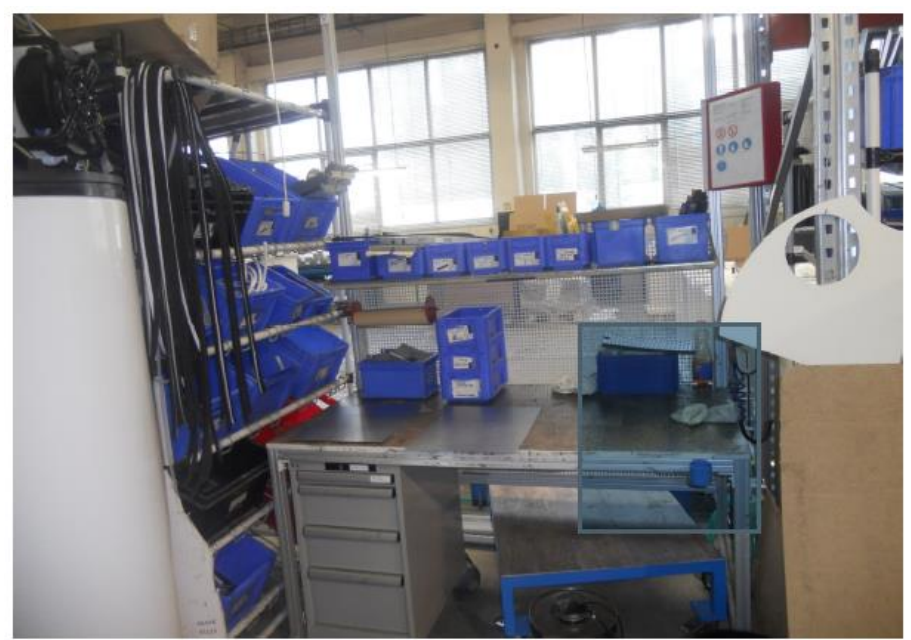

Fig. 8. Workstation of pre-assembly.

\subsection{Analysis of the future state}

After changing the input data, the new calculation of material flows was performed. The changes especially included:

- decreasing the amount of material being manipulated, from the weekly stock to the daily need,

- changing the way of material's transport,

- reducing inter-storages in production halls,

- changing the plant's layout (creating the supermarket),

- changing transport routes. 
The results of analysis show that:

- total length of material flows is $2,841,074.88 \mathrm{~m} /$ year,

- total transport costs are $28,896.68 € /$ year,

- number of movements of transport devices is 91,120.15 movement / year,

- total time of manipulation is $279,764.14 \mathrm{~min}$.

Table 2. Utilization of transport devices - future state.

\begin{tabular}{lllll}
\hline Device & Quantity & Busy $(\min )$ & Avail. $(\mathrm{min})$ & Utilization \\
\hline Pallet truck & 4 & $229,963.21$ & $864,000.00$ & 26.62 \\
Fork-lift truck & 1 & $49,800.93$ & $216,000.00$ & 23.06 \\
\hline
\end{tabular}

After generating the possible variants of solutions and based on their comparison, the most favourable variant was selected. After presenting the selected variant and analyses to the management of the enterprise, the decision was made that the enterprise will start the implementation of pull system and of the new supplying system.

\subsection{Summary of expended costs and benefits of implementation of designed solution in the enterprise}

In Table 4, there are costs expended on the purchase of new devices and equipment into the supermarket listed. Its implementation will bring these advantages: [6]

- managed amounts of reduced stock,

- increase of stock turnover rate,

- continuous service of multiple production workstations,

- decrease of the number of operators in the production,

- uninterrupted work of production operator,

- making some production areas free,

- decrease of storage areas,

- fast identification of the stock levels.

Table 4. Costs of supermarket.

\begin{tabular}{ll}
\hline Device & Quantity \\
\hline Racks for the supermarket & $1,815.00$ \\
Labelling of racks and workstations & 91.30 \\
Boards of oversupplies & 90.00 \\
System cart for the supermarket & $33,000.00$ \\
Inductive guidance of the cart & $3,405.19$ \\
Taxi solution & $1,094.00$ \\
New workstations of pre-assembly & $5,796.00$ \\
\hline Total costs of the supermarket & $\mathbf{4 5 , 2 9 1 . 4 9}$ \\
\hline
\end{tabular}


By implementing the Kanban system, following advantages were created in the enterprise: [11], [12]

- decrease of the number of production batches,

- decrease of the downtime,

- improvement of communication,

- improvement of quality,

- decrease of the amount of unfinished production,

- increase of labor productivity,

- lower space requirements,

- decrease of the costs of non-quality,

- making the flow in production clearer,

- easier planning system,

- determination of minimal and maximal stock levels.

Quantifiable benefits of the selected solution are listed in Table 5.

Table 5. Comparison of the current and future state.

\begin{tabular}{|c|c|c|c|}
\hline Parameter & Unit & Current state & Future state \\
\hline Total length of material flows & $\mathrm{m} /$ year & $2,939,224.21$ & $2,841,074.88$ \\
\hline Total costs of transport & $€ /$ year & $38,173.73$ & $28,896.68$ \\
\hline $\begin{array}{l}\text { Number of movements of transport } \\
\text { devices }\end{array}$ & movement / year & $112,305.00$ & $91,121.00$ \\
\hline $\begin{array}{l}\text { Total time of transport and } \\
\text { manipulation }\end{array}$ & $\min /$ year & $349,222.00$ & $279,764.00$ \\
\hline Busy time of pallet trucks & $\min /$ year & $306,081.00$ & $229,963.00$ \\
\hline $\begin{array}{l}\text { Percentage utilization of working } \\
\text { time fund of pallet trucks }\end{array}$ & $\%$ & 35.43 & 26.62 \\
\hline Busy time of fork-lift trucks (FT) & $\min /$ year & 2 FT: $43,141.37$ & 1 FT: $49,800.93$ \\
\hline $\begin{array}{l}\text { Percentage utilization of working } \\
\text { time fund of fork-lift truck }\end{array}$ & $\% /$ year & 9.99 & 23.06 \\
\hline $\begin{array}{l}\text { Area allotted for storage racks in the } \\
\text { storehouse }\end{array}$ & $\mathrm{m}^{2}$ & 145.10 & 217.42 \\
\hline Transport area in the storehouse & $\mathrm{m}^{2}$ & 221.80 & 115.50 \\
\hline
\end{tabular}

Besides the listed benefits, the number of fork-lift trucks needed dropped, interstorages were eliminated, stock on production workstations was reduced by $80 \%$, and one production operator was made vacant by the creation of new assembly workstations by the supermarket, which represents saving of $18,000 € /$ year.

The return on invested funds according to the enterprise is listed in Table 6. One of the enterprise's criteria while selecting the projects is the necessity of the return on investment until 2 years. This was also the reason of choosing just this option by the enterprise. 
Table 6. Return on investment.

\begin{tabular}{ll}
\hline Cost of implementation & Price $(€)$ \\
\hline Costs of the supermarket & $42,291.49$ \\
Costs of Kanban & 580.00 \\
Total costs & $42,871.49$ \\
Annual saving of transport costs & $9,277.05$ \\
Annual saving of costs on production operator & $18,000.00$ \\
Total savings & $27,277.05$ \\
Calculation of return on investment & total costs / total savings \\
\hline Return on investment & $\mathbf{1 . 5 7}$ year \\
\hline
\end{tabular}

Acknowledgements. This paper was made about research work support: VEGA 1/0936/16.

\section{References}

1. Šramová, V., Závodská, A., Lendel, V.: Reintegration of Slovak Researchers Returning to Slovak Companies. L. Uden et al. (Eds.): KMO 2015, LNBIP 224, pp. 353-364. DOI: 10.1007/978-3-319-21009-4_27 (2015)

2. Vodák, J., Soviar, J., Lendel, V.: The Proposal of Model for Building Cooperation Management in Company. In: Verslas: Teorija ir praktika / Business: Theory and Practice. pp. 65 - 73. ISSN 1648-0627. doi:10.3846/btp.2015.535 (2015)

3. Krajčovič, M., Rakyta, M., Křížová, E., Bubeník, P., Gregor, M.: Industrial logistics. Žilina: EDIS. 2004. p. 375. ISBN 80-8070-226-8 (2004)

4. Harris, R., Harris, C., Wilson, E.: We create material flows. Žilina: SLCP. 2009. p. 92. ISBN 978-80-89333-11-0 (2009)

5. Weng, W., Song, Y., Yang, G., Schnidt, R.: PFEP - oriented in plant logistics planning method for assembly plants. In: ICLEM 2010: Logistics for Sustained Economic Development - Infrastructure, Information, Integration. ISBN 978-078441139-1. Doi: $10.1061 / 41139(387) 192(2010)$

6. Smalley, A.: We make a balanced pull. Žilina: SLCP. 2009. p. 115. ISBN 978-80-89333-103 (2009)

7. Nallusamy, S.: Lean manufacturing implementation in a gear shaft manufacturing company using value stream mapping. In International Journal of Engineering Research in Africa. ISSN 1663-4144, vol. 21, pp. 231-237. Doi: 10.4028/www.scientific.net/JERA.21.231 (2015)

8. Mičieta, B., Gregor, M., Quirenc, P., Botka, M.: Kanban - you are to pull! 1st ed. (Žilina : SLCP). ISBN 80-968324-2-5 (2001)

9. Mičieta, B., Botka, M.: KANBAN system and its implementation problems. In Annals of DAAAM for 2002 \& Proceedings of the 13th international DAAAM symposium "Intelligent manufacturing \& automation: learning from nature". pp. 353-354. Vienna: DAAAM International. ISBN 3-901509-29-1 (2001)

10. Sulírová, I., Rakyta, M., Bjalončíková, J.: Lean logistics trends. In: InvEnt 2016: industrial engineering - toward the smart industry: proceedings of the international conference. pp. 148-151. Žilina: University of Žilina, 2016. - ISBN 978-80-554-1223-8. (2016) 
11. Krajčovič, M.: Stocks in milk-run system. In: Produktivity and innovation. pp. 2-4. ISSN 1335-5961. - vol. 11, no. 1 (2010) (2010)

12. Gall, R., Minda, M., Baumgartner, M., Rakyta, M.: Process improvement of the production system by using lean manufacturing tools. In: InvEnt 2014: industrial engineering navigating the future: proceedings of the international conference. pp. 178-181. Žilina: CEIT, 2014. - ISBN 978-80-554-0879-8. - CD-ROM (2014) 